Journal of the Egyptian Society of Parasitology, Vol.43, No.3, December 2013 J. Egypt. Soc. Parasitol., 43(3), 2013: 649 - 656

\title{
HETEROBOTHRIUM LINEATUS (MONOGENEA: DICLIDOPHORIDAE) INFECTING THE GILLS OF THE NILE PUFFER TETRAODON LINEATUS (PISCES: TETRAODONTIDAE) FROM THE RIVER NILE, EGYPT WITH A NEW LOCALIT RECORD: A LIGHT AND SCANNING ELECTRON MICROSCOPIC STUDY
} By

KAREEM S. MORSY ${ }^{1}$, MONA FATHI KHALIL ${ }^{2}$, IRENE SAMEH GAMIL ${ }^{2}$, AHMED SALEM ELEBIARIE ${ }^{2}$, AND ROKIA MAHMOUD IBRAHIM ${ }^{2}$

Department of Zoology ${ }^{1}$, Faculty of Science, Cairo University and Department of Zoology and Entomology ${ }^{2}$, Faculty of Science ${ }^{2}$, Helwan University, Cairo, Egypt

\begin{abstract}
Heterobothrium lineatus (Monogenea: Diclidophoridae) is described from the gills of Tetraodon lineatus collected from the River Nile at Helwan governorate, Egypt as a new locality record. The morphology and morphometric characterization of the recovered worms were described by means of light and scanning electron microscopy. Twenty two out 35 with a percentage of $62.9 \%$ of the examined fish were infected with Heterobothrium sp. (the intensity of infection was about ten worms per fish in general). Most of the infected fish had very pale gills and showed symptoms of anemia. Morphologically, the adult worms were elongated with anterior pointed and posterior broad ends, it measured 1.15-1.76 $(1.52 \pm 0.02) \mathrm{mm}$ in length $\mathrm{x} 0.28-0.39(0.29 \pm 0.02) \mathrm{mm}$ in width. Two buccal organs situated anteriorly around mouth opening were shown by light and scanning electron microscopy. Haptor subdivided into four pairs of clamps without isthmus separating it from body. The recovered worm differed from the previously species in the same genus by small dimensions of the measurements and presence of a copulatory organ armed with 7-11 genital hooks. Also, it is distinguished from $H$. tetrodonis and $H$. okamotoi by absence of a distinct isthmus, and resembled $H$. lamothei from gills of Sphoeroides testodineus in Mexico and H. lineatus from $T$. lineatus in Egypt in general appearance and presence of rectangular haptor with the fourth pair of clamps smaller than the previous ones.
\end{abstract}

Key words: Heterobothrium lineatus, Monogenea, Diclidophoridae, Tetraodon lineatus, River Nile, Light and scanning electron microscopy.

\section{Introduction}

In Egypt, the studies of fish parasites take a special significance because fish are playing a compensatory source of protein. The presence of parasites devalue the quality and palatabilty of fish and in the most serious cases lower their economic profitabilty.The gills of 
fish represent one of the biotope mostly exploited by different fish ectoparasites (Rohde, 1982). Among these ectoparasites, monogenetic trematodes that cause severe destructions of the gills as well as severe losses too (Morsy et al, 2012). Gills of infested fish were congested or pale haemorrhagic with hypersecretion of mucus. These signs may be due to severe irritation caused by movement, feeding activity, fixation and attachment of monogenean worms. Also, the presence of thick mucous secretion leads to respiratory failure and osmotic stress ending in the fish death. Monogeneans as ectoparasites have well developed attachment structures, anterior one, prohaptor, may comprise a pair of concave disk-like structures, a pair of buccal suckers, head organs (paired glandular duct openings), or a single, weak, oral sucker. Posterior one or haptor is associated with hard (sclerotized) structures in the form of hooks, anchors, clamps. The disease caused by monogenean mainly by diclidophorid, causes serious problems in aquaculture (Okamoto 1963; Ogawa and Inouye 1997; Yoshinaga et al, 2001, 2009; Mushiake et al, 2001; Nakayasu et al, 2002) with an obvious pathogenicity. The immature worms attach to the gill filaments of the hosts and migrate to the buccal cavity wall for maturation, as the worms ingest the blood from the gills of host fish, heavily infected wild and cultured fish become anaemic (Anshary et al, 2001; Yoshinaga et al, 2009). Okamoto and Ogasawara (1965) studied the incidence of parasite infecting wild tiger puffer caught in Japan over a year, found that $17 \%$ of large mature fish were infected with $H$. okamotoi. The Fahaka puffer fish or Nile puffer, Globe fish, Lineatus puffer (Tetraodon lineatus), is a tropical freshwater fish found in the River Nile and other river basins of Africa.

The present study evaluated the natural prevalence of monogenetic trematodes infection with morphologic and morphometric characters of the recovered species by means of light and scanning electron microscopy.

\section{Materials and Methods}

A total of 35 fish of Tetraodon lineatus (Forsskal, 1775) (family: Diclidophoridae) with size $14-28 \mathrm{~cm}$, mean $18.5 \pm 7.15 \mathrm{~cm}$; body weight $100-250 \mathrm{~g}$, mean $205 \pm 20 \mathrm{~g}$ were caught from the River Nile Coast at Helwan district, over the year 2012. The fish were kept alive in aquaria filled with the same water source and examined within few hours. Skin surface, fins and gills were then examined by naked eyes and a dissecting microscope for parasites, lesions and/or pathologic features. After removing opercula and exposing gill arches, each gill was carefully removed and immersed in normal saline to remove any excess gill mucus. The monogenean was recovered with a Pasteur pipette under a dissecting binocular microscope. Worms were fixed in $4 \%$ formalin, washed in distilled water to remove excess fixative and identified in drops of ammonium picrate glycerine under cover slips, and examining hard parts using light microscopy. For permanent preparation, some of the fixed and flattened specimens were 
stained with acid carmine followed by washing in a ascending alcohol series, cleared in clove oil, xylene and then mounted with Canada balsam (Ergens and Dulmaa, 1969). For each parasite, the sclerotized parts of the haptor were measured using an ocular micrometer calibrated against a stage micrometer slide according to Gussev (1985). Ten specimens were measured for the range and the mean \pm standard deviation (SD). Prevalence, mean abundance and measurements after Bush et al. (1997).

\section{Results}

Twenty two out of 35 fish samples (62.9\% infection rate) were infected with Heterobothrium sp. (the intensity of infection was about ten worms per fish). Positive correlation was observed between the increase in size and age of the infected fish and parasite abundance. Most of the infected fish had very pale gills and showed symptoms of anemia.

Adults elongated with pointed an anteriorly containing mouth opening and a posterior broad end containing haptor (Fig. 1). Body length was 1.25-1.79 (1.50 $\pm 0.02) \mathrm{mm}$ and maximum width at midside was $0.28-0.39 \quad(0.29 \pm 0.02) \mathrm{mm}$. There was no isthmus separating haptor from the body, two buccal organs measured 0.025-0.041 $(0.034 \pm 0.002) \mathrm{mm}$ in diameter and just above pharynx measured 0.024-0.046 $(0.039 \pm 0.002) \mathrm{mm}$ in diameter (Fig. 2). Intestinal caeca were spread at body both lateral and middle parts (Fig. 1). Copulatory organ composed of a spherical cup measured 0.010$0.015(0.014 \pm 0.002)$ in diameter supported with 7-11 hooks arranged in a circle
(Figs. 3,4). A large u-shaped ovary with a long oviduct (Fig. 5). Posteriorly, a hookless haptor measured 0.033-0.054 $(0.48 \pm 0.02) \mathrm{mm}$ in width composed of 4 pairs of laterally clamps on both sides (Figs. 6,10,11). Clamps (Figs. 7-9,12-14) were $0.049-0.065 \quad(0.058 \pm 0.02), 0.088$ $0.14 \quad(0.13 \pm 0.02), \quad 0.063-0.082 \quad(0.073 \pm$ $0.02) \& 0.039-0.043(0.044 \pm 0.02) \mathrm{mm}$ in diameter.

\section{Taxonomic summary}

Family: Diclidophoridae Fuhrmann (1928).

Host: The Nile Puffer Tetraodon lineatus (Forsskal, 1775) (Pisces: Tetraodontidae)

Infection site: gills and wall of bronchial cavity.

Locality: River Nile at Helwan, Egypt.

Prevalence: 22/35 fish (62.9\%) were naturally infected.

Etymology: Parasite specific name after fish name isolated for the first time in Egypt.

\section{Discussion}

Genus Heterobothrium (Cerfontaine, 1895) includes twelve species of monogeneans infecting the gills of puffer fishes of the family Tetraodontidae (Williams, 1986; Ogawa, 1991; Victor and Edgar, 2008). These were H. tetrodonis (Goto, 1894) Cerfontaine 1895, H. tonkinensis (Yamaguti, 1958), $H$. ecuadori (Meserve, 1938), H. fluviatilis (Euzet and Birgi, 1975), H. praeorchis (Bychowsky et al, 1976), H. praeorchis (Bychowsky et al, 1976), H. torquigeneri and $H$. elongatum (Williams, 1986), H. okamotoi, H. yamagutii, H. shanagawai, H. bychowskyi and H. lamothei (Ogawa, 1991). These 
species were described from Australian marine waters only $H$. ecuadori (Meserve, 1938) was described from America and none was reported in Egypt except for the same species recovered for the first time from the same host captured from the River Nile at Qena Governorate. Little data was available on the basic ecological features of these parasites that infect puffers in the wild. The taxonomic information only available on these species was from Mexico and Panama (Lamothe-Argumedo, 1996; Ho et al, 2001; Josefina et al, 2004). Twenty two fish (62.9\%) were infected with Heterobothrium sp. with high mortality rates to their host fish; these might be due to the increase in the amount of waste water in this area. These results were in line with (Hirazawa et al, 2003) who stated that the waste water containing infected fish may cause a horizontal transmission, so treatment of these worms was important as these parasites might cause high mortality. The only and most abundant helminth species in puffers with the highest mean intensity was the monogenean Heterobothrium sp. (Josefina et al, 2004). The adults invade gills of their hosts and not only feed on large amounts of blood, with atheir haptoral clamps embedded deeply in muscle tissue of the opercular wall, causing necrosis of epithelial and muscle tissue, and marked infiltration of inflammatory cells and fibroblasts (Anshary et al, 2001; Hirazawa et al, 2003). Several studies of fish showed an increase in parasite abundance with host size or host age. Comparative analyses proved positive relationships between fish size and parasite species richness where the number of parasite species increases regularly with the size of the host. Comparison bet-ween the present parasite and previous one of genus Heterobothrium improved that structurally, the present parasite is similar to that recorded by Morsy et al. (2012) with some differences in the metric data of some parameters. Also, it resembled $H$. lamothei parasiting the gills of Spheroeroides testudineus in Mexico (Victor and Edgar 2008) and H. ecuadori in Florida (Boucher, 1974) in general structures except in number of coronary hooks supporting copulatory organ which are much more in the comparable species. The total length \& width differed also from the present species in being much larger in (Tab. 1). Resemblance between the two species of Heterobothrium from Mexico and Florida and difference from Egyptian ones might be due to geographic and/or climatic factors.

\section{Conclusion}

The present species belongs to genus Heterobothrium and classified as $H$. lineatus (Morsy et al, 2012). Studies on the biology and treatment of Heterobothrium sp. on its hosts are ongoing and will be published soon.

\section{References}

Anshary, H, Ogawa, K, Higuchi, M, Fujii, T, 2001: A study of longterm changes in summer infection levels of Japanese flounder Paralichthys olivaceus with the monogenean Neoheterobothrium hirame in the central Sea of Japan, with an application of a new technique for collecting small parasites 
from the gill filaments. Fish. Pathol. 36:27-32.

Boucher, GC, 1974: Parasites of the checkered puffer, Spheroides testudineus. In Biscayne Bay, Florida, with an analysis of host parasite relationships. MS thesis. The University of Miami, Coral Gables, Florida.

Bush, AO, Lafferty, KD, Lotz, JM, Shostak, AW, 1997: Parasitology meets ecology on its own terms: Margolis et al. revisited. J. Parasitol. 83:575-83.

Bychowsky, BEL, Mamaev-Yu, Naibina, LF, 1976: Revision of the genus Heterobothrium Cerfontaine, 1895 (Diclidophoridae).Trudy-Biologo-Poch -vennogo-Instituta-Issledovaniyamonogenticheskikh-sosal'shchikov,-NovayaSeriya. 34:29-40.

Bykovskaya-Ravlovskay, IE, Gussev, AV, Dubinina, MN, Lzyumova, NA, Smirnova, TS, et al, 1962: Key to Parasites of Fresh Water Fish of the USSR, Akademii Nauk SSSR, Moscow.

Gussev, AV, 1985: Guide to the Parasites of Freshwater Fish of the fauna of USSR. 2, (Ed.O. N.Bauer) lzd. Nauka, Leningrad.

Ergens, R, Dulmaa, A, 1969: Monogenoidea from Cyprinus carpio haematopterus and carassius auratus gibelia (cyprinidae) from Mongolia, Folia Parasitol. (Praha). 16:201-6.

Euzet, L, Birgi, E, 1975: Heterobothrium fluviatilis n. sp. (Monogenea, Diclidophoridae), gill parasite of Tetraodon fahaka Bennett 1834 (Teleostei) in Chad. Bull. de la Soc. Zool. de France 100:411-20.
Ho, J, Gomez S, Fajer, E, 2001: Lepeophtheirus simplex sp. n., a caligid copepod (Siphonostomatoida) parasitic on botete (bullseye puffer, Sphoeroides annulatus) in Sinaloa, Mexico. Folia. Parasitol. 48:240-8.

Josefina, FE, Roque, A, Aguilar, G, Duncan, N, 2004: Patterns of occurrence of the platyhelminth parasites of the wild bullseye puffer (Sphoeroides annulatus) off Sinaloa, Mexico. J. Parasitol. 90, 2:415-8.

Hirazawa, N, Goto, T, Shirasu, K, 2003: Killing effect of various treatments on the monogenean Heterobothrium okamotoi eggs and oncomiracidia and the ciliate Cryptocaryon irrita$n s$ cysts and theronts. Aquaculture 223: 1-13.

Lamothe-Argumedo, R, 1996: Monogéneos de peces. $x$. Especie nueva del género Capsaloides, parásito de Tetrapturus audax de Mazatlan, Sinaloa, México. Ana. Instit. de Biol. Univ. Naci. Autó. México, Ser. Zool. 67:163-71.

Meserve, FGC, 1938: Some monogenetic trematodes from Galapagos Islands and the neighbouring Pacific. Allan Hancock Pacific Expedition 2:31-89.

Mushiake, K, Mori, K, Arimoto, M, 2001: Epizootiology of anemia in wild Japanese flounder. Fish. Pathol. 36: 125-32.

Morsy, KS, Saady, H, Abdel-Ghaffar, F, Bashtar, AR, Mehlhorn, H, et al, 2012: A new species of the genus Heterobothrium (Monogenea: Diclidophoridae) parasitizing the gills of tiger puffer fish Tetraodon lineatus (Tetraodontidae). A light and scanning elect- 
ron microscopic study. Parasitol. Res. 110, 3:1119-24.

Nakayasu, C, Yoshinaga, T, Kumagai, A, 2002: Hematology of anemia experimentally induced by repeated bleeding in Japanese flounder with comments on the cause of flounder anemia recently prevailing in Japan. Fish. Pathol. 37:125-30.

Ogawa, K, Inouye, K, 1997: Heterobothrium infection of cultured tiger puffer, Takifugu rubripes (Teleostei: Tetraodontidae), a field study. Fish. Pathol 32:15-20

Ogawa, K, 1991: Redescription of $\mathrm{He}-$ terobothrium tetrodonis (Goto, 1894) (Monogenea: Diclidophoridae) and other related new species from puffers of genus Takifugu (Teleostei: Tetraodontidae). Jpn. J. Parasitol. 40:111-8.

Okamoto, T, 1963: On the problems of monogenetic trematode infection of puffers from inland sea of Japan. Suisan Zoshoku. 3:17-29.

Okamoto R, Ogasawara, Y, 1965: Parasite occurrences of tiger puffer in natural waters. Ann. Rep. Naikai. Reg. Fish. Lab. Ser. 2:42-3.

Rhode, K, 1982: Ecology of Marine Parasites. University of Queensland Press, St. Lucia, Queensland, Australia.
Victor, M, Edgar, F, 2008: Heterobothrium lamothei n. sp. (Monogenea: Diclidophoridae) from the gills of Spheroeroides testudineus (Pisces: Tetradontidae) from the coast of Yucatan, Mexico. Revista Mexicana de Biodiversidad. 79:895-935.

Williams, A, 1986: Taxonomy of two new species of Heterobothrium (Monogenea: Diclidiophoridae) from Torquigener pleurogramma (Pisces: Tetraodontidae) from Western Australia. Australian J Zool 34:707-715.

Yamaguti, S, 1958: Studies of the Helminth Fauna of Japan. Part 53 Trematodes of Fishes, Xii. Publications of the Seto Marine Biological Laboratory Special Publication Series 7:53-88.

Yoshinaga, T, Kamaishi, T, Segawa, I, Yamano, K, Ikeda, H, et al, 2001: Anemia caused by challenges with the monogenean Neoheterobothrium hira$m e$ in the Japanese flounder. Fish. Pathol. 36:13-20.

Yoshinaga, T, Tsutsumi, HK, Ogawa, K, 2009: Origin of the diclidophorid monogenean Neoheterobothrium hirame Ogawa, 1999, the causative agent of anemia in olive flounder Paralichthys olivaceus. Fish. Sci. 75:116776.

Table 1: Parameters of present Heterobothrium and others (measurments in mm):

\begin{tabular}{|c|c|c|c|c|}
\hline Aspect & $\begin{array}{l}\text { H. lamothei } \\
(\text { Ogawa,1991) }\end{array}$ & $\begin{array}{c}\text { H. ecuadori } \\
\text { (Meserve,1938) }\end{array}$ & $\begin{array}{c}\text { H. lineatus } \\
\text { (Morsy et al, 2012) }\end{array}$ & Present one \\
\hline Total body length & $1.88-3.03$ & $1.30-2.80$ & $1.15-1.76$ & $1.25-1.79$ \\
\hline Maximum body width & $0.270-0.780$ & $0.350-0.850$ & $0.300-0.420$ & $0.28-0.39$ \\
\hline Pharynx width & $0.072-0.120$ & & $0.039-0.051$ & $0.024-0.046$ \\
\hline Buccal organ width & $0.080-0.110$ & & $0.025-0.041$ & $0.019-0.0317$ \\
\hline Copulatory organ width & $0.060-0.095$ & & $0.012-0.019$ & $0.010-0.015$ \\
\hline Opisthohaptor width & $0.045-0.080$ & & $0.030-0.050$ & $0.033-0.054$ \\
\hline \multicolumn{5}{|l|}{ Dimensions of clamps } \\
\hline First pair & $0.120-0.280$ & & $0.052-0.072$ & $0.049-0.065$ \\
\hline Second pair & $0.130-0.290$ & & $0.090-0.150$ & $0.088-0.140$ \\
\hline Third pair & $0.130-0.230$ & & $0.078-0.095$ & $0.063-0.082$ \\
\hline Fourth pair & $0.110-0.210$ & & $0.045-0.065$ & $0.039-0.043$ \\
\hline
\end{tabular}




\section{Explanation of Figures}

Figs. 1-9: Photomicrographs of $H$. lineatus. 1 Adult with anterior attachement organ (AT) equipped by two anterior buccal organs (BO) followed by branches of intestinal caeca (IC) and a posterior haptor (Op) subdivided into 4 pairs of clamps (C). 2-7: High magnifications: 2 Two buccal organs (BO), pharynx (Ph) and copulatory organ (CO). 3,4 Copulatory organ (CO) consisting of a circular cup supplied with a crown of hooks (CR). 5 Part of ovary (OV). 6 Haptor (H) with 4 pairs of clamps (C). 7-9 Clamps (C).
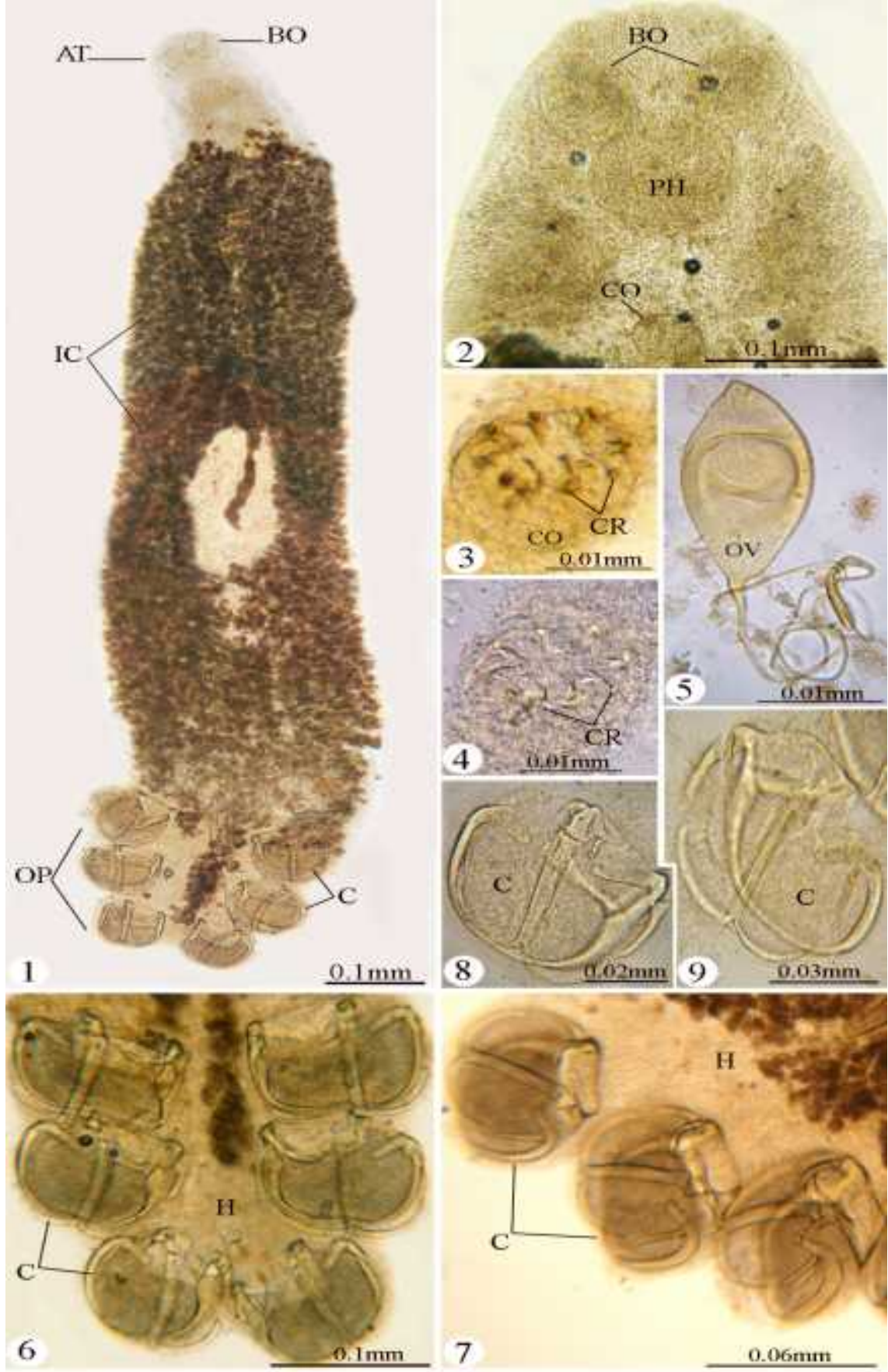
Figs. 10-16: SEM of adult. 10 Dorsal view \& 11 Ventral view of haptors with clamps (C). 12 -14 High magnifications of clamps (C).
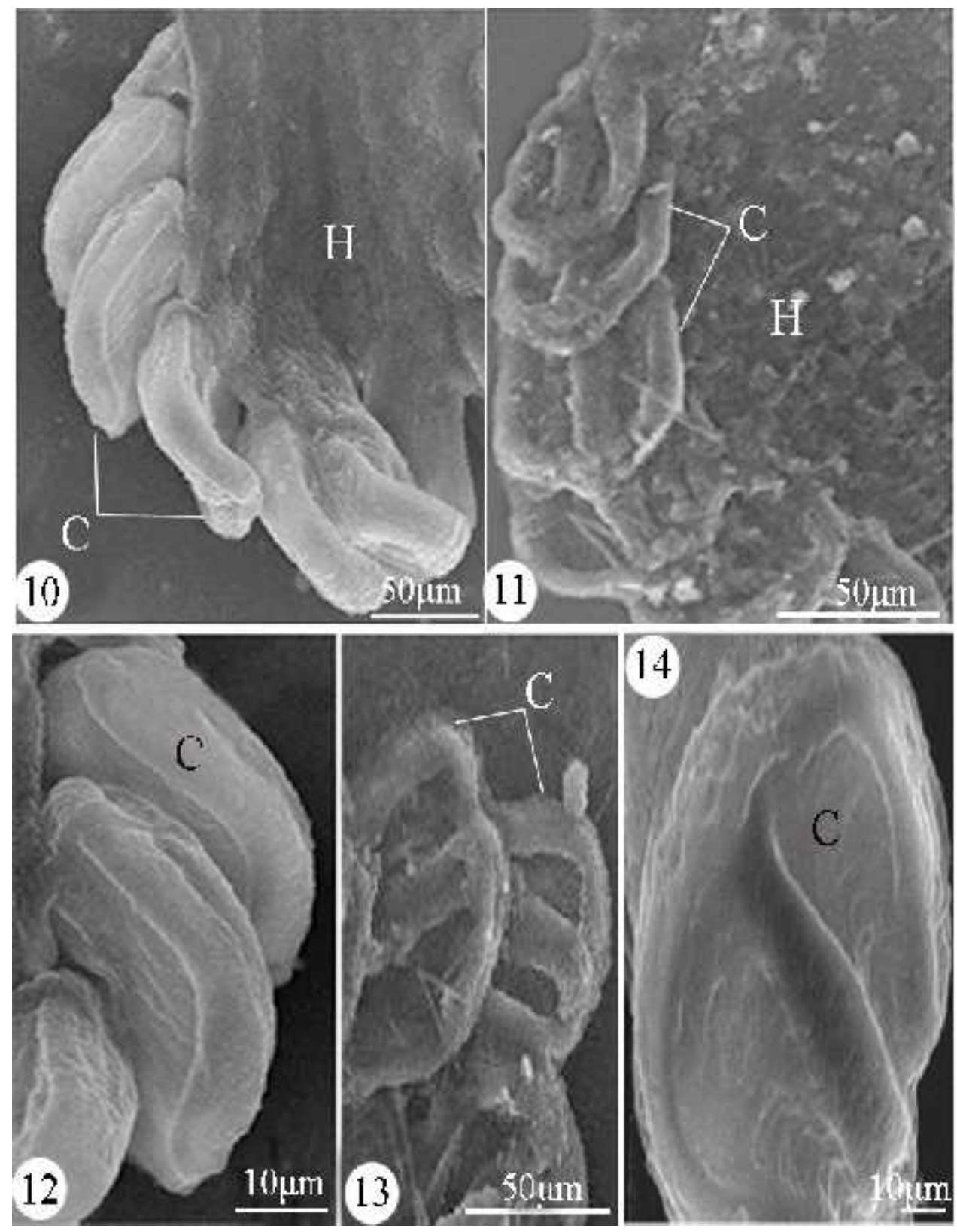